\title{
Diversity of the assessments of a joint leadership model in early childhood education in Finland
}

\section{Fonsén, Elina}

Verlag Barbara Budrich

2019-07

Fonsén , E \& Mäntyjärvi , M 2019 , Diversity of the assessments of a joint leadership model in early childhood education in Finland . in P Strehmel , J Heikka, E Hujala , J Rodd \& M Waniganyake (eds), Leadership in Early Education in Times of Change : Research from five Continents . Verlag Barbara Budrich, Berlin , pp. 154-170 .

https://doi.org/10.2307/j.ctvmd84fc.15, https://doi.org/10.2307/j.ctvmd84fc

http://hdl.handle.net/10138/304446

https://doi.org/10.2307/j.ctvmd84fc. 15

cc_by_sa

publishedVersion

Downloaded from Helda, University of Helsinki institutional repository.

This is an electronic reprint of the original article.

This reprint may differ from the original in pagination and typographic detail.

Please cite the original version. 
Chapter Title: Diversity of the assessments of a joint leadership model in early childhood education in Finland

Chapter Author(s): Elina Fonsén and Marjo Mäntyjärvi

Book Title: Leadership in Early Education in Times of Change

Book Subtitle: Research from five Continents

Book Editor(s): Petra Strehmel, Johanna Heikka, Eeva Hujala, Jillian Rodd, Manjula

Waniganayake

Published by: Verlag Barbara Budrich. (2019)

Stable URL: https://www.jstor.org/stable/j.ctvmd84fc.15

JSTOR is a not-for-profit service that helps scholars, researchers, and students discover, use, and build upon a wide range of content in a trusted digital archive. We use information technology and tools to increase productivity and facilitate new forms of scholarship. For more information about JSTOR, please contact support@jstor.org.

Your use of the JSTOR archive indicates your acceptance of the Terms \& Conditions of Use, available at https://about.jstor.org/terms

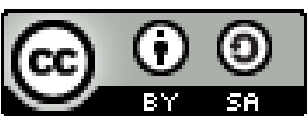

This book is licensed under a Creative Commons Attribution-ShareAlike 4.0 International License (CC BY-SA 4.0). To view a copy of this license, visit

https://creativecommons.org/licenses/by-sa/4.0/.

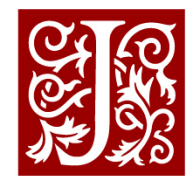

Verlag Barbara Budrich is collaborating with JSTOR to digitize, preserve and extend access to Leadership in Early Education in Times of Change 


\title{
Diversity of the assessments of a joint leadership model in early childhood education
}

\author{
Elina Fonsén, University of Helsinki, Finland \\ Marjo Mäntyjärvi, University of Oulu, Finland
}

\begin{abstract}
This article provides the assessments of a joint leadership model based on research in early childhood education (ECE) leadership in the city of Hämeenlinna, Finland. In this new leadership model, each ECE unit was led by a pair of directors, with one responsible for the financial and human resources aspects and the other responsible for the pedagogy and client processes. The aim of the new leadership model was to strengthen the leadership and pedagogy as the core of leadership. The study explored how the staff members evaluated the quality of leadership within several ECE units. Furthermore, this study examined if there were differences in the assessments of the quality of leadership of the pair of two directors. The quantitative data for the study were collected by an electronic questionnaire completed by ECE directors and staff. Statistically significant differences were found in the assessments of the units led by the same director pair. The parallel line in high and low assessments indicated that satisfaction or dissatisfaction with leadership was a holistic way to see the impact of leadership on the organisational culture of the units. The findings drew attention to the question of how the conditions that were necessary for distributed leadership should be supported.
\end{abstract}

\section{German Abstract}

Dieser Artikel stellt die Untersuchung eines Modells geteilter Führung in der Stadt Hämeenlinna in Finnland vor. In diesem neuen Modell wurden die Kindertageseinrichtungen von zwei Führungskräften geleitet, die eine verantwortlich für die finanziellen und personellen Ressourcen und die andere für die Prozesse in der pädagogischen Arbeit und in der Zusammenarbeit mit den Eltern. Die Ziele dieses neuen Leitungsmodells war es, die Führung zu stärken und die Pädagogik in Richtung einer Kernaufgabe von Leitung zu bewegen. Die Studie erkundete, wie das Personal die Qualität der Leitung in mehreren Einrichtungen bewertete. Außerdem prüfte die Studie, ob es Unterschiede in der Einschätzung der Leitungsqualität zwischen den beiden Leitungskräften gab. Die quantitativen Daten der Studie wurden mit einem elektronischen Fragebogen erhoben, der von Fach- und Leitungskräften ausgefüllt wurde. Statistisch signifikante Unterschiede wurden in den Beurteilungen, der Einrichtungen gefunden, die von den gleichen Leitungstandems geführt wurden. Die parallelen Linien der hohen und niedrigen Bewertungen, deuten darauf hin, dass die 
Zufriedenheit oder Unzufriedenheit mit der Leitung ein ganzheitlicher Weg ist, um die Wirkung der Leitung auf die Organisationskultur der Einrichtungen zu erkennen. Die Ergebnisse ziehen die Aufmerksamkeit auf die Frage, wie die Bedingungen, die für verteilte Führung notwendig sind, unterstützt werden können.

\section{Finnish Abstract}

Tässä artikkelissa tarkastellaan varhaiskasvatuksen uuden yhteisen johtajuusmallin arviointia Hämeenlinnassa, Suomessa. Yhteisen johtajuuden mallissa varhaiskasvatusyksiköitä johtaa johtajapari, joista toinen on vastuussa taloudesta ja henkilöstöstä ja toinen johtaja vastaa pedagogiikasta ja asiakasprosesseista. Johtajuusmallin tavoitteena on vahvistaa johtajuutta ja pedagogiikkaa johtamisen keskiössä. Tässä tutkimuksessa tarkastellaan henkilöstön antamia arviointeja johtajuudesta varhaiskasvatusyksiköissä. Tarkastelun kohteena on erityisesti johtajaparien eri yksiköiden arviointien erot. Kvantitatiivinen aineisto kerättiin sähköisenä-kyselynä johtajilta ja henkilöstöltä. Joidenkin johtajaparien eri yksiköiden henkilöstöjen antamien johtajuusarviointien erot osoittautuivat tilastollisesti merkitseviksi. Sekä korkeat että matalat arvioinnit näyttivät noudattavat samankaltaista yhtenevää linjaa ja näyttäisi siten olevan kokonaisvaltainen organisaation kulttuurinen tapa tarkastella johtajuutta kyseisissä yksiköissä. Tulosten perusteella on tärkeää kiinnittää huomiota siihen, miten voitaisiin tukea johtajuuden kehittämisen taustalla olevia organisaation olosuhteita.

\section{Introduction}

Due to the continual changes in early childhood education (ECE) in Finland, the existing state of affairs can be defined as follows. The administration of ECE in Finland is the responsibility of the Ministry of Education and Culture and the services are regulated by the Act on Early Childhood Education and Care (2015). The National Core Curriculum on Early Childhood Education (2016) guides all Finnish ECE provision, stating that municipalities are responsible for ECE services. In particular, $84 \%$ of children in ECE are in services provided by municipalities while $16 \%$ are in private services (Repo \& Vlasov, 2017). Finnish educational professionals are widely respected and enjoy relatively autonomous working conditions based on the implementing the national core curriculum. This can be seen as a strength of the pedagogical quality of the services. Previous research has shown a need for a focus to develop the quality of ECE services, pedagogy and the pedagogical leadership of ECE (Eskelinen, Halttunen, Heikka \& Fonsén, 2015, p. 82; Fonsén \& Vlasov, 2017).

The Act on Qualifications Requirements for Social Welfare Professionals $(272 / 2005)$ states that a director of an ECE unit must be a qualified ECE teacher and have adequate management and leadership skills. The directors usually work as administrative directors and are responsible for a number of units and 
employees. In Finland, an ECE centre may consist of many ECE units of different sizes (from one to several groups) but also it may include different forms of ECE services, not only all-day care in groups but also part time and pre-school services. The number of employees needed follows the ratio set in the ECE act. However, it seems that the directors' responsibilities are not clearly defined (Eskelinen et al., 2015). In such a situation, administrative tasks concerning human resources and economic matters are shifting the focus of directors away from pedagogy and towards these other issues. High-quality pedagogy would need directors to reflect on and develop pedagogical practices with the ECE practitioners who work with children (Fonsén, 2013, 2014; Parrila \& Fonsén, 2016).

Early childhood education in Finland has faced many reforms in recent years. The administrative shift from the Ministry of Social Affairs and Health to the Ministry of Education and Culture, new legislation and the new National Core Curriculum took place between 2013 and 2017. Due to these numerous changes, it has also been necessary to redefine the leadership of ECE. This study examines the implementation of the new joint ECE leadership model in one Finnish municipality (for more, see Fonsén, Akselin, \& Aronen, 2015; Keski-Rauska, Fonsén, Aronen \& Riekkola, 2016). In this model, management and leadership functions were distributed between two directors: the finance and human resources director and the pedagogy and client processes director.

\section{Joint leadership in the new model of the ECE leadership}

The change of the leadership model of ECE in the City of Hämeenlinna occurred from the beginning of 2014. The aim of developing the new joint ECE leadership model was to bring the core task of ECE, pedagogy, to the centre of the leadership focus. The pedagogical development of ECE was considered in order to require strong pedagogical leadership. The previously implemented concept of multi-dimensional leadership was considered to be challenging. The tasks of financial and personnel management were emphasised for several years. It was noticed that directors' opportunities to emphasize pedagogy were limited. The development of pedagogy and pedagogical leadership was restricted due to the expanded focus on administrative tasks.

As a result of the changes, the pairs of directors were given the responsibility for leading each ECE unit. Under this joint leadership model, one of the directors is responsible for the financial and human resources and the second director is responsible for the pedagogy and client process. The director who is responsible for the financial and the human resources is officially the manager responsible for the staff, while the director responsible for pedagogy and client processes leads the process of pedagogical work. In addition, the directors share the responsibility for pedagogical development. In the Hämeenlinna ECE joint 
leadership model, each work pair has two to five physically-separated ECE units. (Aronen, Fonsén \& Akselin, 2014a, 2014b.)

The aim of the joint leadership model has been to strengthen the ECE directors' leadership through their own leadership positions. However, the central element of the change in the leadership model has become distributed leadership with a pair of directors. Essential for the director pair's development of joint leadership and the creation of practical structures were mutual time resources, common discussion, evaluation and critical consideration of issues. At the same time, the individual directors have developed their work in their own leadership position. (Aronen et al., 2014a, 2014b.)

Having a director pair replaces the role of having an individual director in the organisation (Gronn, 1999). In order to succeed, the leadership by two directors must be able to create a common vision and to communicate it credibly to their community. Directors must have a common understanding of the direction in which they lead their units. (Houni, Ansio \& Järvinen, 2013; see also Akselin, 2013.) Miles and Watkins (2007) use the term "complementary leadership", where leadership is shaped by interacting with team members who complement each other. The success of complementary leadership is promoted by a shared vision, reciprocal encouragement, good interaction and trust. However, changing structures to joint leadership is not enough. At the same time, it is important to look at people's agency in the organisation and to clarify both professionalism and the professional relationships (Halttunen, 2009).

As a result of the development work of directors' own leadership functionality, a second element was the vertical perspective of joint leadership referring to joint leadership interaction between the staff and the directors. Joint leadership challenged the staff to focus on a new kind of leadership. This required time and space for both the two directors and the staff to learn about the joint leadership model. Joint leadership was seen largely as being based on interaction, which was supposed to become deeper over time between people in a familiar and secure framework (Keski-Rauska et al., 2016).

McDowall, Clark and Murray (2012) emphasize the re-definition of leadership, which involves seeing shared leadership as a collective commitment and a common process for all participants. In the joint leadership model, leadership is divided horizontally with the working pairs of directors. In addition, the perspective of the vertically distributed leadership is present by sharing the common vision and mission with all members of the organisation. The process of making a joint effort emphasizes dialogue and the building of a new common reality, taking into account the multitude forms of leadership. (Ropo et al., 2006; Viitala, 2005, p. 188).

An earlier study of the joint leadership model in Hämeenlinna (Keski-Rauska et al., 2016) showed that the assessments of the quality of leadership by the 
staff were different from the assessments made by the directors. The directors were more satisfied, while the staff did not consider the joint leadership model to be as successful. The prerequisite for developing a model was to find a time to examine, discuss and clarify the structures and practices. Particularly important in the development of the new leadership model was the sharing of leadership as both a horizontal pair of workers and as a vertical divide between the directors and staff. In the working communities, common joint leadership builds trust and promotes the commitment of all parties to a common goal. (Kocolowski, 2010; Keski-Rauska et al., 2016.)

\section{Research questions}

The purpose of the study was to investigate leadership assessments in several ECE units that were the responsibility of a pair of directors. The quality of the joint leadership model has been examined using the leadership assessment tool (Hujala \& Fonsén, 2009, 2010a, 2012; Hujala, Roos, Nivala \& Elo, 2014).

The research questions are:

1) How do the staff evaluate the quality of joint leadership in several ECE units?

2) Are there any differences in the quality assessments of joint leadership between the ECE units under the responsibility of the director pair?

\section{Conducting the research}

The assessment of leadership in Hämeenlinna's ECE was implemented in August 2015 by distributing an electronic survey questionnaire to the ECE-centre directors and staff. The assessment tool (Appendix 1) has been developed as one of the ECE quality and leadership development projects at the University of Tampere to evaluate the quality of leadership and work well-being. The questionnaire comprises 41 items in six themes concerning leadership dimensions. (Hujala \& Fonsén, 2009; 2010a; 2012; Hujala et al., 2014.)

The assessment tool was based on an earlier national ECE curriculum, the National Core Curriculum for Early Childhood Education and Care (2005). The theoretical basis of assessment is in pedagogical leadership theory (Fonsén, 2009) and contextual ECE leadership research (Nivala, 1998, 1999; Hujala \& Puroila, 1998; Puroila, 2004; Nivala \& Hujala, 2002), a day care quality assessment model (Hujala-Huttunen, 1995; Hujala, Parrila, Lindberg, Nivala, Tauriainen \& Vartiainen, 1999; Hujala \& Fonsén, 2010b) and work on well-being studies (Mäkipeska \& Niemelä, 2005; Juuti, 2006). 
The assessment of leadership questionnaire contains six themes:

- pedagogical leadership

- support for well-being at work

- information and communication

- working atmosphere and community

- distributed leadership

- quality factors

The pedagogical leadership theme is related to the implementation of the ECE curriculum. The items evaluate how the work community has created common practices for pedagogical discussion and how these are realized. The support for work well-being at work theme is related to human resource management, such as the implementation of development discussions with staff and the director's support in problematic situations. The information and communication theme covers both internal information issues and communication within the organisations. The working atmosphere and community theme assesses the interaction between staff, and the staff's experience of their successes in the work and their sense of work relevance. Issues related to the distributed leadership theme evaluate the personnel's own responsibility to promote the work community's performance in the skills of leadership and responsibility for the quality of work shared with director and staff. The quality factors theme assess the items that measure the structural aspects of the early childhood education organisation. These include the size and structure of child groups, the support of leadership and organisational structure for pedagogical activities, as well as the practices of co-operation with partners. (Hujala \& Fonsén, 2009; 2010a; 2012; Hujala et al., 2014).

The questionnaire was sent to $486 \mathrm{ECE}$ staff members (including directors) in Hämeenlinna, and 233 of these responded, giving a response rate of $48 \%$. The responders were teachers $(n=214)$ and directors $(n=19)$. The participants' consent to participate in the research was obtained and they were informed about the aims of the research.

The responses were provided according to a five-point Likert scale, with assessment 1 standing for the lowest quality level and assessment 5 standing for the highest. The sum score of means was calculated for all six themes. The total sum of leadership was modelled from all 41 items. Statistical tests were performed by using SPSS software. The internal consistency of the dimensions was computed using Cronbach's alphas. The reliability of the tested dimensions was good (Cronbach's Alpha: .738 - .845), when a reliability coefficient of .70 or higher is considered acceptable (Heikkilä, 2008). 


\section{Results}

In this study, the assessment of the leadership of early childhood education units $(\mathrm{N}=22)$ was examined separately for each director pair $(\mathrm{N}=9)$. Among the total ECE units $(n=27)$, five units were removed from the data, because only one response had been received. Differences in quality assessments were examined using non-parametric tests due to the small size of the data sample. The Mann-Whitney $U$ test measured the statistical significance of the difference between the two units and the Kruskal-Wallis test was used to test the statistical significance of differences between more than two units (Table 1). Significant differences were found between the assessments of the different units under the response of the same director pair.

Table 1. Leadership quality assessments in ECE units under the responsibility of director pairs

\begin{tabular}{|c|c|c|c|}
\hline Director pair & $\begin{array}{l}\text { The total sum of leadership } \\
\text { assessment in the units }\end{array}$ & \multicolumn{2}{|c|}{$\begin{array}{l}\text { Significance between the } \\
\text { tested groups }\end{array}$} \\
\hline A & Unit 1 (3.36) Unit 2 (3.75) & Mann Whitney U & p. $=.003 * *$ \\
\hline B & Unit $3(3.70)$ Unit 4 (3.32) & Mann Whitney U & $p .=.087$ \\
\hline C & $\begin{array}{c}\text { Unit } 5 \text { (3.63) Unit } 6(3.73) \\
\text { Unit } 7(4.18)\end{array}$ & Kruskal-Wallis & p. $=.005^{* *}$ \\
\hline D & Unit $8(3.50)$ Unit $9(3.58)$ & Mann Whitney U & $p .=392$ \\
\hline$E$ & $\begin{array}{c}\text { Unit } 10 \text { (3.88) Unit } 11(3.80) \\
\text { Unit } 12(4.19)\end{array}$ & Kruskal-Wallis & p. $=.150$ \\
\hline $\mathrm{F}$ & $\begin{array}{c}\text { Unit } 13 \text { (4.19) Unit } 15 \text { (3.63) } \\
\text { Unit } 16(3.30)\end{array}$ & Kruskal-Wallis & p. $=.000 * * *$ \\
\hline G & Unit 17 (3.58) Unit 18 (3.80) & Mann Whitney U & p. $=149$ \\
\hline $\mathrm{H}$ & Unit 21 (3.78) Unit 22 (3.46) & Mann Whitney U & p. $=142$ \\
\hline 1 & $\begin{array}{c}\text { Unit } 24 \text { (4.09) Unit } 25 \text { (3.99) } \\
\text { Unit } 26(3.31)\end{array}$ & Kruskal-Wallis & p. $=.000 * * *$ \\
\hline
\end{tabular}

The differences in the quality assessments between the units were not statistically significant in the units of five pairs of directors, (56\% of the director pairs), but the differences between the quality assessments of the units that were the responsibility of four director pairs were statistically significant $(44 \%$ of the director 
pairs). The difference between 11 units (50\%) had no statistically significant difference in quality results and the difference between 11 units (50\%) that were the responsibility of the same leader pair was statistically significant.

In two cases, the director pair had three units that they were responsible for, and the differences between the assessments of the units were statistically very significant $\left.{ }^{* * *}=\mathrm{p}<.001\right)$. Closer inspection was made of the units that were the responsibility of two director pairs, (director pair F and director pair I). In Figure 1, the parallel line indicates how the means of all six leadership themes vary in units led by director pair F. Only issues related to the atmosphere and work well-being revealed a small deviation in the assessments of unit 15, which was slightly lower than the ratio of the corresponding variable of the other units to the other sum variables.

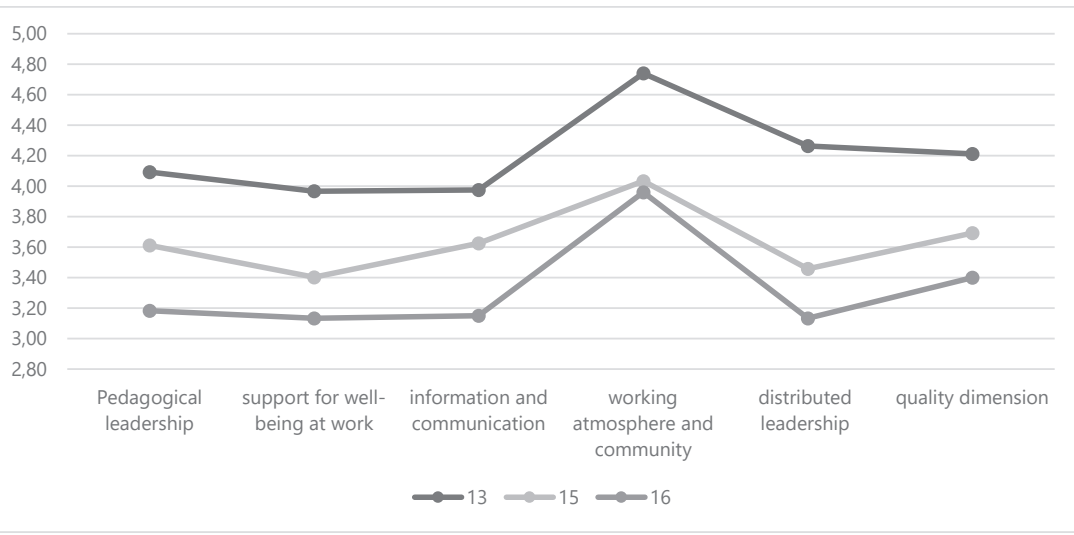

Figure 1. The sum score of means in different themes in the Units (13, 15 and 16) under the response of director pair $F$

A parallel tendency can also be observed in Figure 2. The sum score of means of all six leadership themes varies as an almost parallel line in the units for which director pair I are responsible. However, in this case, the assessment of distributed leadership in unit 25 is somewhat higher than the assessments of the other units. In two other units (24 and 26), distributed leadership was lower than the assessments of the other themes. 


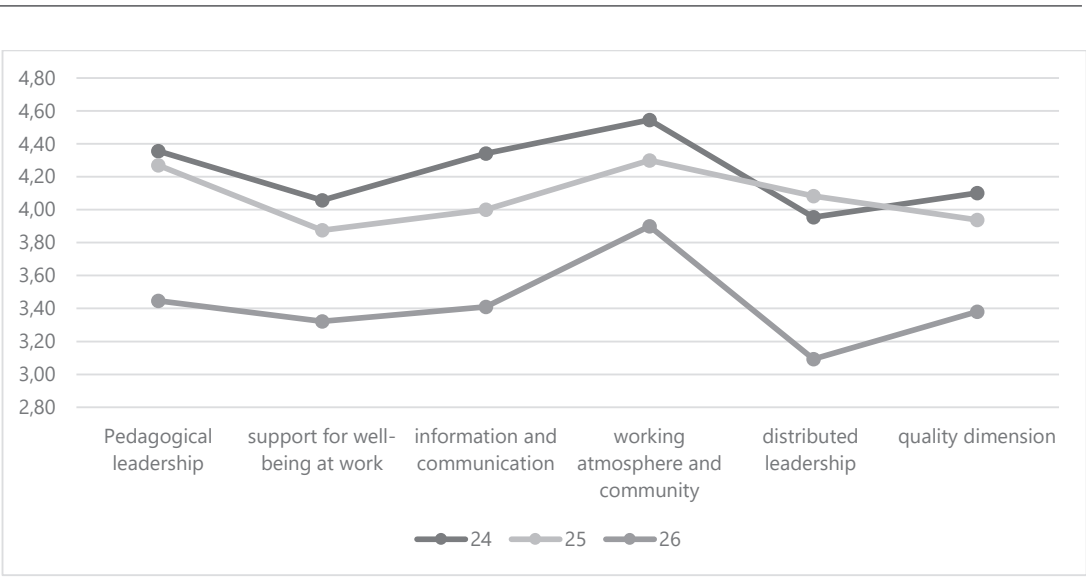

Figure 2. The sum score of means in different themes in the Units (24, 25 and 26) under the response of director pair I

It is interesting that in both cases the highest and the lowest assessments are almost in line with each other. The highest assessments are in the working atmosphere and community theme in both director pair units. The lowest assessments are clearer in the distributed leadership theme in the units of director pair I, while the assessments in the units of director pair $\mathrm{F}$ are as low as or slightly lower in the support of the work well-being theme and the information and communication theme than for the distributed leadership theme.

\section{Discussion}

The parallel lines of high and low assessments indicate that satisfaction or dissatisfaction with leadership is related to seeing leadership as part of an organisational culture in a holistic way. The same phenomena were found in discursive research in the same context in 2017 (Fonsén \& Keski-Rauska, 2018). In the e-mail interview with the child group staff in the units that director pair I and F were responsible for, the staff were asked to discuss the results of the leadership assessment in 2015 and write a summary of the discussion. The analysis of the staff members' discussions indicated that the units which received the highest assessments had the strongest discourse on joint leadership and trust and that had empowered the staff. In the units which received the lowest assessments, more critical discourse was found in the speech which reflected instability and uncertainty.

Distribution of leadership is not yet obvious in the joint leadership model. In addition, the results of an earlier study by Keski-Rauska et al. (2016) indicated that the teachers did not yet consider the joint leadership model to be 
entirely successful, but the directors were more satisfied. The current study indicates that vertical distribution requires more clarification and common understanding. Interestingly, the highest (4.19) and the lowest (3.30) ratings received by the units were in the results of the same director pair (F). The organisational culture in units and the circumstances of the units may vary. Many simultaneous changes, such as the changes of the personnel and in the leadership system, require stronger support in the organisation.

In addition, the early stage of the new leadership model and the new arrangement of the leadership in the municipality may produce the limitations in the reliability of the research. The different number of changes in the personnel and the directors in the units may have had an impact on the assessments of leadership. In some cases, the director pair may be new, while in the other cases, a familiar director was continuing.

The challenges of joint leadership found in the earlier study were the following dimensions of joint leadership: time, interaction, situation, and diversity (Keski-Rauska et al., 2016). Time for reflection and discussion is needed while developing joint leadership towards a common shared understanding at both horizontal and vertical levels of the distributed leadership. Furthermore, the clarification of practices and structures is required, as well as permanency in interactions, communication, and relationships. Transparency, confidence and empowerment are needed for the implementation of the new leadership model equally in every ECE unit. (Figure 3.) As was mentioned earlier (Aronen et al., 2014a, 2014b), and as the results of the current study also shows, the essential for the development of joint leadership is the creation of practical structures for leadership as well as mutual time resources, common discussion, evaluation and critical consideration of issues.

As Kocolowski (2010) argues, shared leadership is quite a complicated thing to implement, but the benefits of it are evident. Harris and Spillane (2008) claim that to succeed, distributed leadership requires a lot of planning and functional structures in the organisation as well as continuous development. The organisational structure needs to be clarified, so it can support the pedagogical structure. Furthermore, Halttunen (2009) has pointed out, that is necessary to redefine all participants' roles and responsibilities during periods of organisational change. Currently, it seems that Hämeenlinna's ECE directors have clarified their own roles and the distribution of leadership between their positions. Furthermore, crucial in the process of implementing the new leadership model is to build the confidence of all participants. As McDowall Clark and Murray (2012) argue, shared leadership as a collective commitment and a mutual process for all participants needs a re-definition of leadership. Vertical distribution is a prerequisite to success in the implementation of the joint leadership model. It supports well-be- 
ing at work and while the work atmosphere is good, it leads to opportunities to enhance professionalism and the quality of pedagogy.

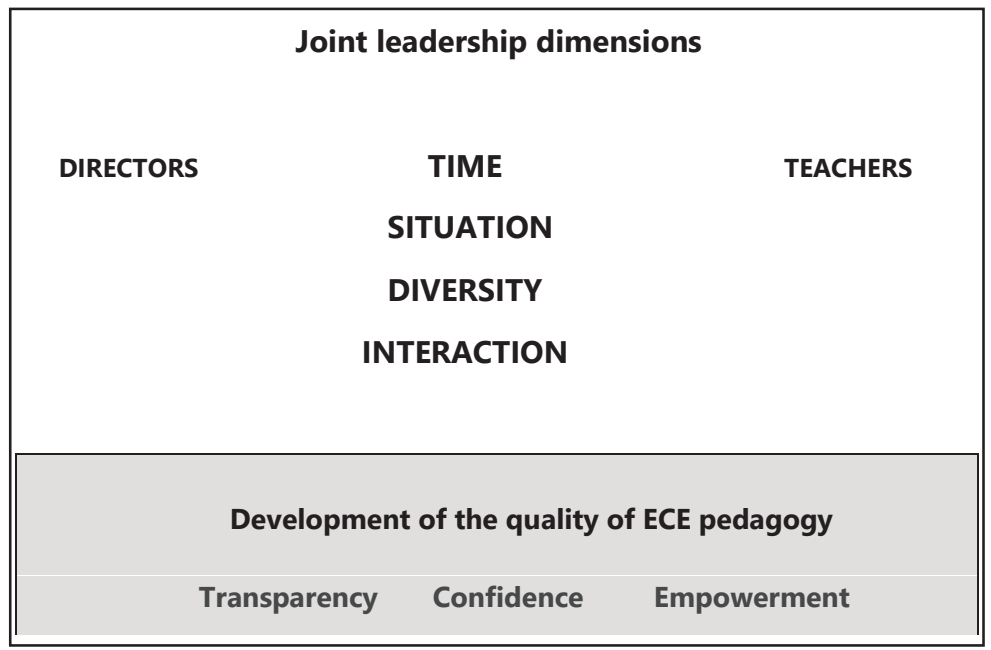

Figure 3. Outlines of quality of joint leadership (Fonsén \& Keski-Rauska, 2018)

\section{Conclusions}

The results emphasise that the situation in the ECE units differs, and this leads to demands for different kinds of leadership. The process of change from ordinary leadership to the joint leadership model seems to progress gradually. In the units, the process of change has reached various stages, and the staff can experience it differently. The diversity of leadership assessments may be related to several changes happening in the organisation at the same time. The diversity may also be constructed through different discourses in the organisations (see also Soukainen \& Fonsén, 2018). Change can be seen as an opportunity or as a threat; it may be experienced as exhausting or it may offer the opportunity for empowerment. The directors should have enough time to get to know the discourses in every unit, to be aware of the specific needs that manifest themselves. This means that transparency is needed in communication. In addition, the teacher's professional knowledge, experience and training and the pedagogical skills may be varied, and the staff's need for pedagogical leadership differs. This requires time and discussion between the staff and the director pair. Thus, attention should also be paid to the professional and reflection skills of the director pairs. Puroila and Kinnunen (2017) showed how the renewed Early Childhood and Care Act 
challenges directors to improve pedagogical leadership and this is recognised by Finnish professionals nationally. The most critical question regarding successful joint leadership with the aim of improving the quality of ECE can be seen as the demand for directors' professionalism and the requirement for ECE directors' training and further training.

\section{References}

Act on Early Childhood Education and Care (2015).

Act on Qualifications Requirements for Social Welfare Professionals (272/2005).

Akselin, M-L (2013). Varhaiskasvatuksen strategisen johtamisen rakentuminen ja menestymisen ennakoiminen johtamistyön tarinoiden valossa. Doctoral dissertation. Acta Universitatis Tamperensis 1807. Tampere: Tampere University Press.

Aronen, K., Fonsén, E., \& Akselin, M-L. (2014a). Jaetusta johtajuudesta yhteiseen johtajuuteen. Case: Hämeenlinnan päiväkotien johtajuuden kehittämisen alkutaival. Hämeenlinna: The city of Hämeenlinna.

Aronen, K., Fonsén, E., \& Akselin, M-L. (2014b). Kohti yhteistä johtajuutta. Premissi, 9 (4), 30-33.

Eskelinen, M., Halttunen, L., Heikka, J., \& Fonsén, E. (2015). Early childhood landscape in Finland and reflective comments on Australia and Norway. In M. Waniganayake, J. Rodd \& L. Gibbs (Eds.) Thinking and Learning about Leadership: Early childhood research from Australia, Finland and Norway (82-86). International Leadership Research Forum (ILRF) Research Monograph \#2. Sydney: Community Childcare Cooperative NSW.

Fonsén, E. (2009). Pedagoginen johtajuus - varhaiskasvatustyön johtamisen punainen lanka. Masters's thesis. Acta Universitatis Tamperensis 1914. Tampere: Tampere University Press. Retrieved from http://tampub.uta.fi/handle/10024/80562

Fonsén, E. (2013). Dimensions of Pedagogical leadership in Early Childhood Education and Care. In E. Hujala, M. Waniganayake \& J. Rodd (Eds.), Researching Leadership in Early Childhood Education (181-192). Tampere: Tampere University Press.

Fonsén, E. (2014). Pedagoginen johtajuus varhaiskasvatuksessa. Doctoral dissertation. Acta Universitatis Tamperensis 1914. Tampere: Tampere University Press.

Fonsén, E., Akselin, M-L., \& Aronen, K. (2015). From distributed leadership towards joint leadership - a case study: the early stages of developing a new ECE leadership model for the city of Hämeenlinna. In M. Waniganayake, J. Rodd \& L. Gibbs (Eds.) Thinking and Learning about Leadership: Early childhood research from Australia, Finland and Norway. International Leadership Research Forum (ILRF) Research Monograph \#2. Sydney: Community Childcare Cooperative NSW, 116-130.

Fonsén, E. \& Keski-Rauska, M-L. (2018). Varhaiskasvatuksen yhteinen johtajuus vastakohtaisten diskurssien varassa. Työelämän tutkimus 3/2018. http://www.tyoelamantutkimus.fi/category/tt-lehti/

Fonsén, E. \& Vlasov, J. (2017). Leading Pedagogical Quality in the Context of Finnish Child Care. In C. Ringsmose \& G. Kragh-Müller (Eds.), The Nordic Social Peda- 
gogical Approach to Early Years (253-265). Series: International Perspectives on Early Childhood Education and Development, Vol. 15. Cham: Springer International Publishing AG.

Gronn, P. (1999). Substituting for Leadership: The Neglected Role of the Leadership Couple. Leadership Quarterly, 10 (1), 41-62.

Halttunen, L. (2009). Päivähoitotyö ja johtajuus hajautetussa organisaatiossa. Doctoral dissertation. Jyväskylä Studies in Education, Psychology and Social Research 375. Jyväskylä: Jyväskylä University Printing House, Finland.

Harris, A. \& Spillane, J. (2008). Distributed leadership through the looking glass. Management in Education, 22 (1), 31-34.

Heikkilä, T. (2008). Tilastollinen tutkimus. Helsinki: Edita.

Houni, P., Ansio, H., \& Järvinen, M. (2013). Kaksin aina kauniimpaa? Uusi parijohtajuus suomalaisessa teatterissa. In H. Ansio and P. Hirkman (Eds.) Työ ja johtajuus liminaalitilassa (34-42). Raportti 6/2013. Helsinki.

Hujala, E., \& Fonsén, E. (2009). Loppuraportti. Johtajuus ja varhaiskasvatuksen laatu-projekti. Tampereen yliopisto. Opettajankoulutuslaitos. Varhaiskasvatuksen yksikkö.

Hujala, E., \& Fonsén, E. (2010a). Työyhteisön pedagoginen kehittäminen työhyvinvoinnin perustana päivähoidossa -projektin loppuraportti. Tampereen yliopisto, Opettajankoulutuslaitos, Varhaiskasvatuksen yksikkö.

Hujala, E., \& Fonsén, E. (2010b). Varhaiskasvatuksen laadun vahvuudet ja kehittämiskohteet. Lastentarha, 73 (2), 8-11.

Hujala, E., \& Fonsén, E. (2012). Verkostoista voimaa pedagogiseen johtamiseen laatua ja työhyvinvointia varhaiskasvatukseen. Loppuraportti. Tampereen yliopisto. TSR.

Hujala, E., \& Puroila, A-M. (1998). Towards Understanding Leadership in Early Childhood Context - Cross-cultural Perspectives. Acta Universitatis Ouluensis. Series E 35. Oulu: University Press.

Hujala, E. Parrila, S., Lindberg, P., Nivala, V., Tauriainen, L., \& Vartiainen, P. (1999) Laadunhallinta varhaiskasvatuksessa. Oulun yliopisto. Varhaiskasvatuskeskus.

Hujala, E., Roos, P., Nivala, V., \& Elo, J. (2014). Osaamisella työhyvinvointia varhaiskasvatuksessa. Tampere: Juvenes Print.

Hujala-Huttunen, E. (1995). Varhaiskasvatuksen laadunarviointi. [Early childhood education quality assessment]. In E. Hujala-Huttunen \& E. Estola (Eds.) Näkökulmia varhaiskasvatukseen. Oulun lastentarhanopettajaopiston julkaisuja. $69-82$.

Juuti, P. (2006). Johtaminen ja työyhteisön hyvinvointi. In P. Vesterinen (Ed.) Työhyvinvointi ja esimiestyö (77-91). Helsinki: WSOYpro

Keski-Rauska, M-L., Fonsén, E., Aronen, K., \& Riekkola, A. (2016). Research on a joint leadership model for early childhood education in Finland. Journal of Early Childhood Education Research, 5 (2), 310-328. Retrieved from http://jecer.org/ fi/wp-content/uploads/2016/12/Keski-Rauska-Fonsen-Aronen-Riekkola-issue5-2.pdf

Kocolowski, M.D. (2010). Shared Leadership: Is it Time for a Change? Emerging Leadership Journeys, 3 (1), 269-282.

McDowall Clark, R., \& Murray, R. (2012). Reconceptualizing leadership: leadership in the early years. Maidenhead: Open University Press. 
Miles, S. A. \& Watkins, M. D. (2007). The Leadership Team: Complementary Strengths or Conflicting Agendas? Harvard Business Review (online). Retrieved from <https://hbr.org/2007/04/the-leadership-team-complementarystrengths-or-conflicting-agendas $>$ Red 5.10.2017.

Mäkipeska, M. \& Niemelä, T. (2005). Haasteena luottamus - työyhteisön sosiaalinen pääoma ja syvärakenne. Helsinki: Edita

National core curriculum for early childhood education and care (2005). Stakes oppaita 56.

National Core Curriculum on early childhood education and care 2016 (2016). The Finnish National Agency for Education.

Nivala, V. (1998). Theoretical perspectives on educational leadership. In E. Hujala \& A-M. Puroila (Eds.) Towards Understanding Leadership in Early Childhood Context - Cross-cultural Perspectives. Acta Universitatis Ouluensis. E 35. Oulu: University Press.

Nivala, V. (1999). Päiväkodin johtajuus. Doctoral dissertation. Acta Universitatis Lapponiensis 25. Rovaniemi: University Press.

Nivala, V. \& Hujala, E. (2002). Leadership in Early Childhood Education - Cross Cultural perspectives. Acta Universitatis Ouluensis. E 57. Oulu: University Press.

Parrila, S. \& Fonsén, E. (2016). Varhaiskasvatuksen pedagoginen johtajuus. Käsikirja käytännön työhön. Jyväskylä: PS-kustannus.

Puroila, A-M. (2004). Työ varhaiskasvatuksessa muuttunut yhä vaativammaksi. In Päiväkodin johtaja on monitaituri. Lastentarhanopettajaliitto, 20-24.

Puroila, A-M. \& Kinnunen, S. (2017). Report on the impacts of amendments to early childhood education and care legislation. (Selvitys varhaiskasvatuksen lainsäädännön muutosten vaikutuksista) Publications of the Government's analysis, assessment and research activities 78/2017.

Repo, L., \& Vlasov, J. (2017). Tilastoraportti. Varhaiskasvatussuunnitelman toimeenpanon arviointi. Kansallinen koulutuksen arviointikeskus.

Ropo, A., Eriksson, M., Sauer, E., Lehtimäki, H., Pietiläinen, T., \& Koivunen, N. (2006). Jaetun johtajuuden särmät. Helsinki: Talentum.

Soukainen, U. \& Fonsén, E. (2018). Will the Leadership Last? Sustainable Leadership in Early Childhood Education. In A. Višnjić Jevtić \& A. Jurčevč - Lozančić (Eds.) Early Childhood Relationships: The foundation for Sustainable Future Proceedings (293-310). International Scientifical and Professional Conference OMEP 2017.

Viitala, R. (2005). Johda osaamista. Osaamisen johtaminen teoriasta käytäntöön. Keuruu: Otavan kirjapaino Oy. 


\section{Appendix 1}

The assessment of the quality of leadership

\section{Pedagogical leadership}

1. The work community has achieved mutual agreement for pedagogical conversation practices.

2. The teams have created mutual agreement for pedagogical planning practices.

3. The pedagogical practices of ECE are discussed in the work community's mutual conversations.

4. The work community's pedagogical conversation practices are actualized as agreed.

5. The teams' pedagogical planning practices are actualized as agreed.

6 . The core tasks of ECE are defined in the work community's mutual conversations.

7. The director implements pedagogical leadership in everyday work.

8. The director is aware of and interested in the educational activities of our group.

9. The early childhood education plan is implemented as practical pedagogy.

10. The children's individual early childhood education plans are implemented as practical pedagogy.

11 . The work community evaluates early ECE practices and develops them according to the assessment.

12. Joint discussions on mission and values are reflected in pedagogical activity.

\section{Support for well-being at work}

13. Employees have the opportunity to receive professional guidance.

14. Development discussions for employees are implemented.

15. Employees have the opportunity to participate in service training and additional education.

16. The working conditions, such as ergonomic dimensions, safety, tools, etc. are appropriate.

17. The director supports employees in problematic situations.

18. The director evaluates the work community's action and develops it according to the assessment.

\section{Information and communication}

19. The flow of information within the work community is functional, transparent, and fair.

20. Information about current issues of ECE in the entire municipal organisation is available to all. 
21. There are functional communication practices between the work community and the ECE administration.

22. All members of the work community are aware of the main tasks and job descriptions.

The working atmosphere and community

23. The work community's atmosphere is open and accepting.

24. The work community's mutual communication is proper and takes its members into account.

25. I feel successful in my work.

26. I consider my work meaningful.

27. I can influence issues concerning my own work.

\section{Distributed leadership}

28. Employees have the power of decision in matters relating to the work community.

29. Leadership is distributed, and leadership responsibilities are shared with director and employees.

30. The responsibility for pedagogical development is shared in the work community.

31. Employees contribute to the community's common work goals through their own actions.

32. Employees contribute to the functionality of the relationship between the director and personnel through their own actions.

33. Employees evaluate the work community's action and develop it based on their assessment.

\section{The quality dimension}

34. The child group size and consistency are premeditated and functional.

35 . The physical environment of child care is appropriate.

36. Attention has been paid to the stability of the human relationships.

37. Leadership supports pedagogically high-quality everyday practices.

38. The structures of child care organisation support pedagogically high-quality everyday practices (e.g. the extent of the kindergarten director's area of responsibility is manageable).

39. Cooperation practices between the parents and the personnel are functional. 40. Cooperation practices between the personnel and partners (therapists, school, etc.) are functional.

41. Personnel are interested in professional development. 
This content downloaded from 128.214.88.117 on Fri, 09 Aug 2019 09:49:54 UTC All use subject to https://about.jstor.org/terms 